\title{
AMPH Gene
}

National Cancer Institute

\section{Source}

National Cancer Institute. AMPH Gene. NCI Thesaurus. Code C20714.

This gene is involved in endocytosis and synaptic transmission. 